\title{
Copolymerization of Carbon Monoxide and Norbornene with a Palladium Catalyst
}

\author{
Der-Jang LiAW* and Biing-Ferng LAY \\ Department of Chemical Engineering, National Taiwan Institute of Technology, \\ Taipei, Taiwan 106, Republic of China \\ (Received August 7, 1995)
}

\begin{abstract}
Carbon monoxide and norbornene $(\mathrm{NBE})$ with $\mathrm{Pd}\left(\mathrm{CH}_{3} \mathrm{COO}\right)_{2}$ under various conditions were copolymerized at $90^{\circ} \mathrm{C}$. Elemental analysis, infrared spectra and NMR spectra showed that the copolymers contained ketone and ring structures. Bidentate nitrogen and phosphorus ligands were more effective ligands to stabilize catalytic activity than monodentate arsenic or phosphorus ligands. Methanol and the protonic acid served as coinitiator and chain-transfer agents. X-Ray diffraction analysis shows the copolymer to be partially crystalline. Thermogravimetric analysis showed that the copolymer started to lose mass at $350^{\circ} \mathrm{C}$ and that maximum decomposition occurred at $447^{\circ} \mathrm{C}$. The $\mathrm{NBE} / \mathrm{CO}$ copolymer obtained from various ligands has a glass transition temperature $\left(T_{\mathrm{g}}\right)$ in the range $100-126^{\circ} \mathrm{C}$. Hydrogenation of norbornene/CO copolymer with a reducing agent yielded a hydroxy-containing polymer.
\end{abstract}

KEY WORDS Copolymerization / Polyketone / Carbon Monoxide / Norbornene / Palladium Catalyst /

Many authors discuss the copolymerization of carbon monoxide and olefins. ${ }^{1-37}$ The first example of copolymerization of carbon monoxide and olefins involved free-radical-initiated copolymerization of $\mathrm{CO}$ and ethylene at high pressure and high temperature. A random copolymer of only small molar mass was obtained. ${ }^{1,2}$ Copolymerization of $\mathrm{CO}$ and olefins is of interest for the following reasons. ${ }^{3}$ First, $\mathrm{CO}$ is cheap. Secondly, polymers containing polyketones have the potential to become photodegradable ${ }^{4-6}$ or biodegradable polymers in a new class. Thirdly, because the carbonyl group can be easily modified chemically, such polyketones are expected to be excellent starting materials for a synthesis of functional polymers of new types. ${ }^{7,8}$

According to several patents, ${ }^{9-12}$ the copolymerization of $\mathrm{CO}$ and ethylene with palladium catalysts yields polyketones of large molar mass; the catalytic systems all require reaction temperatures above $100^{\circ} \mathrm{C}$. Sen et al. developed cationic $\mathrm{Pd}(\mathrm{II})$ compounds to catalyze copolymerization of $\mathrm{CO}$ with various olefins under mild conditions. ${ }^{13,14}$ They report that only cooligomer (molar mass $=350$ ) is obtained from copolymerization of $\mathrm{CO}$ and norbornene for three days. ${ }^{13}$ Although the syntheses of copolymers of $\mathrm{CO}$ with norbornene or 5-norbornene2,3-dicarboxylic anhydride are patented, ${ }^{15,16}$ only a few experimental results have been reported.

We reported previously the copolymerization of $\mathrm{CO}$ and 1,3-cyclopentadiene by palladium complexes. ${ }^{17}$ Phosphorus compounds were found more effective to stabilize ligands for catalytic activity than arsenic or nitric ligands. ${ }^{17}$ Here, we present results on the copolymerization of $\mathrm{CO}$ and norbornene under various conditions at $90^{\circ} \mathrm{C}$. The structure of the copolymer was determined from IR, ${ }^{1} \mathrm{H}$ NMR and solid-state ${ }^{13} \mathrm{C}$ NMR spectra. The effects of stabilizing ligand on catalytic activity, solvent, ligands and oxidant with regard to molar mass and yield, and other physical properties are discussed.

\footnotetext{
* To whom all correspondence should be addressed.
}

\section{EXPERIMENTAL}

\section{Materials}

Carbon monoxide (99.3\% purity) was purchased (Air Products and Chemicals Inc.). Norbornene (Merck) was distilled twice from calcium hydride under dry nitrogen (purity $>99 \%$ by GC). Catalyst $\mathrm{Pd}\left(\mathrm{CH}_{3} \mathrm{COO}\right)_{2}$ and oxidants (nitrobenzene, 1,4-naphthoquinone, 1,4-benzoquinone) were purchased from Merck, Germany. Ligands 2,2-bipyridine and 1,10-phenanthroline (Merck), 5-nitro1,10-phenanthroline (TCI), 1,3-bis(diphenylphosphino)propane, triphenylphosphine, triphenylarsine, and triphenylamine (Janssen), were used directly without purification. Solvents were purified according to standard methods.

\section{Copolymerization of $\mathrm{CO}$ and Norbornene}

The alternating copolymerization of $\mathrm{CO}$ and norbornene was conducted in a magnetically stirred stainlesssteel reactor (volume $250 \mathrm{ml}$ ), according to the general procedure of ref $36 . \mathrm{Pd}\left(\mathrm{CH}_{3} \mathrm{COO}\right)_{2}(0.022 \mathrm{~g} ; 0.1 \mathrm{mmol})$, 2,2-bipyridine $(0.47 \mathrm{~g} ; 3 \mathrm{mmol})$, nitrobenzene $(2.05 \mathrm{ml}$; $20 \mathrm{mmol})$, and $p$-toluenesulfonic acid $(0.36 \mathrm{~g} ; 2 \mathrm{mmol})$, were dissolved in tetrahydrofuran (THF) $(10 \mathrm{ml})$ and charged into the reactor. Norbornene $(9.42 \mathrm{~g} ; 0.1 \mathrm{~mol})$ and $\mathrm{CO}(2.3 \mathrm{MPa})$ were added, and the system was heated to $90^{\circ} \mathrm{C}$. After a given period $(2 \mathrm{~h})$, the reaction was quenched to room temperature and unreacted $\mathrm{CO}$ was vented. The product, a fine powder, was recovered by filtration, washed several times with methanol and dried in vacuum. The yield was about $3.02 \mathrm{~g}$. The polymer did not melt below $225^{\circ} \mathrm{C}$. Anal. Found: C, $77.86 \%$; $\mathrm{H}, 8.12 \%$; O, $13.11 \%$; Calcd for a $1: 1$ copolymer $\left(\mathrm{C}_{7} \mathrm{H}_{10} \mathrm{CO}\right): \mathrm{C}, 78.65 \% ; \mathrm{H}, 8.25 \% ; \mathrm{O}, 13.10 \%$. The copolymer structure was proposed as follows:

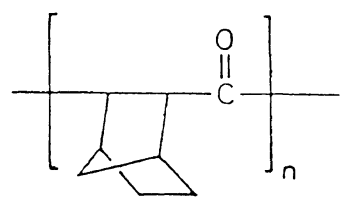


Osmometric measurements showed that the NBE/CO copolymer obtained from THF has a number molar mass $\left(\bar{M}_{n}\right)$ ca. 6100. Polymerization degree $(n)$ was about 50 .

The above procedure was used in other reactions where the temperature, time, pressure, solvent, the proportion of methanol, the concentration of acid and oxidant, and the added ligand were varied

\section{RESULTS AND DISCUSSION}

\section{Copolymerization of $\mathrm{CO}$ with Olefins}

The results of copolymerization of $\mathrm{CO}$ and various olefins with catalyst palladium acetate in methanol are shown in Table I. As indicated, norbornene (NBE) is an effective olefin for copolymerization with carbon monoxide. The infrared spectrum of the product includes two features at 1725 and $1688 \mathrm{~cm}^{-1}$ for $\mathrm{NBE} / \mathrm{CO}$ copolymer in $\mathrm{CH}_{3} \mathrm{OH}$ that are attributed to carbonyl groups in ketones (repeating unit) and esters (end group), respectively. As described previously, ${ }^{17)}$ the formation of polyketoester $\mathrm{RO}-(-\mathrm{CO}-\mathrm{NBE}-)_{n}-\mathrm{COOR}$ (in which $\mathrm{R}=\mathrm{CH}_{3}$ ), is considered to result from copolymerization in the polymer end with an alcohol as solvent. ${ }^{18)}$

The NBE/CO copolymer was insoluble in dimethylacetamide, dimethylsulfoxide, $N, N$-dimethylformamide, pyridine, xylene, benzene, toluene, acetonitrile, 1,2dichloroethane, $m$-cresol, and acetone, but soluble in tetrahydrofuran, chloroform, sulfuric acid, and chlorobenzene.

Copolymerization with the Addition of Various Ligands The influence of ligands on copolymerization of nor-

Table I. Copolymerization of $\mathrm{CO}$ and olefins with a palladium complex ${ }^{\text {a }}$

\begin{tabular}{|c|c|c|c|}
\hline \multirow{2}{*}{$\begin{array}{c}\text { Olefin } \\
\text { monomers }\end{array}$} & Yield & Productivity & $v_{\mathrm{C}=\mathrm{O}}$ \\
\hline & $\mathrm{g}$ & g copolymer $\mathrm{g}^{-1} \mathrm{Pd} \mathrm{h}^{-1}$ & $\mathrm{~cm}^{-1}$ \\
\hline Styrene & 1.93 & 91 & 1747,1703 \\
\hline Hexene & 0.74 & 35 & 1728,1691 \\
\hline Norbornene & 11.34 & 533 & 1725,1688 \\
\hline Phenylacetylene & 0.044 & 2 & 1798,1752 \\
\hline
\end{tabular}

${ }^{\text {a }}$ Experimental conditions: olefin $(0.1 \mathrm{~mol})$; methanol $(10 \mathrm{ml})$; partial pressure of $\mathrm{CO}, \quad \mathrm{P}(\mathrm{CO})=3.3 \mathrm{MPa} ; \quad \mathrm{Pd}\left(\mathrm{CH}_{3} \mathrm{COO}\right)_{2} \quad(0.1 \mathrm{mmol})$; 2,2'-bipyridine ( $3 \mathrm{mmol})$; $p$-toluenesulfonic acid $(2 \mathrm{mmol})$; nitrobenzene $(20 \mathrm{mmol})$; temperature, $90^{\circ} \mathrm{C}$; reaction period, $2 \mathrm{~h}$. bornene with $\mathrm{CO}$ is shown in Table II. Bidentate ligands, 2,2-bipyridine, 1,10-phenanthroline, 5-nitro-1,10phenanthroline, and 1,3-bis(diphenylphosphino)propane and monodentate ligands, triphenylphosphine, triphenylarsine, and triphenylamine were used. According to Table II, the activity of nitrogen and phosphorus bidentate ligands in copolymerization of NBE with $\mathrm{CO}$ clearly exceeded that of monodentate ligands. Drent et al. ${ }^{18}$ reported that the two phosphine groups of a bidentate ligand are likely to bind exclusively in a cis configuration to a single palladium center. This effect maximizes the concentration of species for which propagation is possible.

Phosphines show greater activity than arsenic or nitrogen compounds. Among phosphorus compounds, lower activity of catalyst was observed when less basic ligands such as $\mathrm{P}(\mathrm{OPh})_{3}$ were used instead of $\mathrm{PPh}_{3}$. It is possible that in the presence of less basic ligands, $\mathrm{CO}$ is bound too strongly to the $\mathrm{Pd}(\mathrm{II})$ center, thus poisoning the catalyst. ${ }^{14,17}$ The NBE/CO copolymer obtained from various ligands has a glass transition temperature $\left(T_{\mathrm{g}}\right)$ in the range $100-126^{\circ} \mathrm{C}$. Two absorption features in the IR spectra in $\mathrm{CH}_{3} \mathrm{OH}$ are attributed to ketone and ester carbonyl groups. As NBE/CO copolymers obtained from 1,4-benzoquinone as oxidant were insoluble in common organic solvents such as THF, chloroform, benzene, and chlorobenzene, we could not measure the molar mass by vapour-pressure osmometry.

\section{Effect of Temperature on Copolymerization}

The data of copolymerization yield and molar mass $\left(\bar{M}_{n}\right)$ for various temperatures $\left(T_{\mathrm{p}}\right)$ are plotted in Figure 1. Both the yield and $\bar{M}_{n}$ increased initially and then decreased. This may be due to two competing effects. ${ }^{19}$ Increasing $T_{\mathrm{p}}$ increases $R_{\mathrm{p}}$ (tangent of the curve) but decreases the solubility of the monomer. However, maximum $\bar{M}_{n}$ is at $T_{\mathrm{p}}=90^{\circ} \mathrm{C}$, compared to the maximum yield at $T_{\mathrm{p}}=110^{\circ} \mathrm{C}$. This difference reflects the contribution of the activation energy to chain-transfer processes. ${ }^{19}$ When the temperature exceeded $130^{\circ} \mathrm{C}$, the copolymers were insoluble in common organic solvents such as THF and chlorobenzene. This may have resulted from partial cross-linking of $\mathrm{NBE} / \mathrm{CO}$ copolymer at high temperature.

Table II. Effect of ligand of copolymerization on norbornene and $\mathrm{CO}$ at $90^{\circ} \mathrm{C}^{\mathrm{a}}$

\begin{tabular}{|c|c|c|c|c|}
\hline \multirow{2}{*}{ Ligands } & Yield & Productivity & $T_{\mathrm{g}}^{\mathrm{b}}$ & $v_{\mathrm{C}=\mathrm{o}}$ \\
\hline & $\mathrm{g}$ & g copolymer $\mathrm{g}^{-1} \mathrm{Pd} \mathrm{h}^{-1}$ & ${ }^{\circ} \mathrm{C}$ & $\mathrm{cm}^{-1}$ \\
\hline 2,2-Bipyridine & 7.10 & 334 & 111 & 1727,1692 \\
\hline 1,10-Phenanthroline & 7.89 & 371 & 113 & 1728,1692 \\
\hline 5-Nitro-1,10-phenanthroline & 5.99 & 282 & 112 & 1727,1692 \\
\hline 1,3-Bis(diphenylphosphino)propane & 1.24 & 58 & 126 & 1727,1693 \\
\hline Triphenylphosphine, $\mathrm{PPh}_{3}$ & 0.66 & 31 & 120 & 1725,1687 \\
\hline Triphenylarsine, $\mathrm{AsPh}_{3}$ & 0.60 & 28 & 100 & 1726,1690 \\
\hline Triphenylamine, $\mathrm{NPh}_{3}$ & 0.48 & 23 & 105 & 1729,1694 \\
\hline Triphenylphosphate, $\mathrm{P}(\mathrm{OPh})_{3}$ & 0.15 & 7 & - & - \\
\hline
\end{tabular}

a Experimental conditions: norbornene $(0.1 \mathrm{~mol})$; methanol $(10 \mathrm{ml})$; partial pressure of $\mathrm{CO}, \mathrm{P}(\mathrm{CO})=3.0 \mathrm{MPa} ; \mathrm{Pd}\left(\mathrm{CH}_{3} \mathrm{COO}\right)_{2}(0.1 \mathrm{mmol})$; ligands $(3 \mathrm{mmol}) ; p$-toluenesulfonic acid $(2 \mathrm{mmol}) ; 1$,4-benzoquinone $(20 \mathrm{mmol})$; temperature, $90^{\circ} \mathrm{C}$; reaction period, $2 \mathrm{~h}$. ${ }^{\mathrm{b}}$ Measured by DSC; heating rate, $20^{\circ} \mathrm{C} \mathrm{min}^{-1}$. 


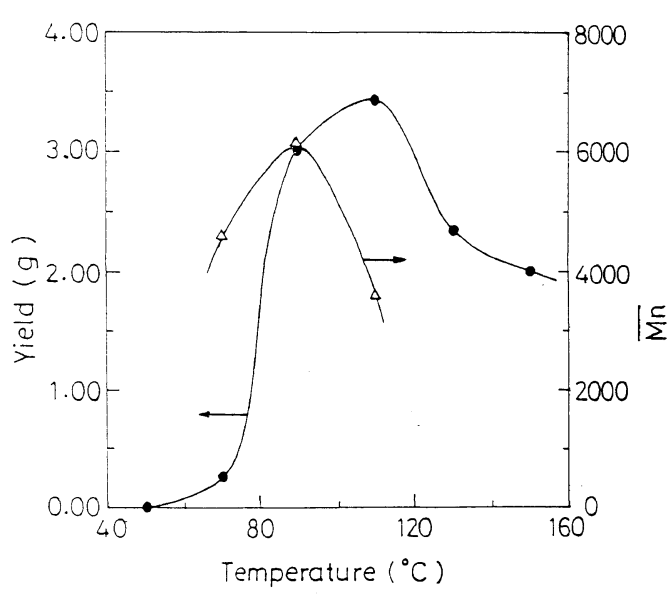

Figure 1. Copolymerization yield and molar mass $\left(\bar{M}_{n}\right)$ at various temperatures $\left(T_{\mathrm{p}}\right)$. Experimental conditions: norbornene $(0.1 \mathrm{~mol})$; methanol $(10 \mathrm{ml})$; partial pressure of $\mathrm{CO}, \mathrm{P}(\mathrm{CO})=2.7 \mathrm{MPa}$; $\mathrm{Pd}\left(\mathrm{CH}_{3} \mathrm{COO}\right)_{2}(0.1 \mathrm{mmol}) ; 2,2^{\prime}$-bipyridine $(3 \mathrm{mmol}) ; p$-toluenesulfonic acid $(2 \mathrm{mmol})$; nitrobenzene $(40 \mathrm{mmol})$; reaction duration, $2 \mathrm{~h} . \bar{M}_{n}$ was measured by osmometry for the copolymer in THF.

Table III. Copolymerization of norbornene and $\mathrm{CO}$ in various solvents ${ }^{\mathrm{a}}$

\begin{tabular}{|c|c|c|c|}
\hline \multirow{2}{*}{ Solvents } & Yield & Productivity & $v_{\mathrm{C}=\mathrm{O}}$ \\
\hline & $\mathrm{g}$ & g copolymer $\mathrm{g}^{-1} \mathrm{Pd} \mathrm{h}^{-1}$ & $\mathrm{~cm}^{-1}$ \\
\hline $\mathrm{CH}_{3} \mathrm{OH}$ & 11.91 & 560 & 1727,1691 \\
\hline $\mathrm{CHCl}_{3}$ & 1.40 & 66 & 1691 \\
\hline THF & 0.73 & 34 & 1688 \\
\hline $\mathrm{C}_{6} \mathrm{H}_{6}$ & 0.59 & 28 & 1689 \\
\hline
\end{tabular}

${ }^{a}$ Experimental conditions: norbornene $(0.1 \mathrm{~mol})$; solvent $(10 \mathrm{ml})$; partial pressure of $\mathrm{CO}, \mathrm{P}(\mathrm{CO})=3.3 \mathrm{MPa} ; \mathrm{Pd}\left(\mathrm{CH}_{3} \mathrm{COO}\right)_{2}(0.1 \mathrm{mmol})$; $2,2^{\prime}$-bipyridine $(3 \mathrm{mmol}) ; \quad p$-toluenesulfonic acid $(2 \mathrm{mmol}) ; 1,4-$ naphthoquinone $(20 \mathrm{mmol})$; temperature, $90^{\circ} \mathrm{C}$; reaction period, $2 \mathrm{~h}$.

\section{Copolymerization of Norbornene and $\mathrm{CO}$ in Various Solvents}

Table III shows that the yield of copolymerization in a protonic solvent (such as $\mathrm{CH}_{3} \mathrm{OH}$ ) exceeds that of copolymerization in an aprotonic solvent (such as $\mathrm{CHCl}_{3}, \mathrm{THF}$, and $\mathrm{C}_{6} \mathrm{H}_{6}$ ). A protonic solvent serves as both co-initiator and chain-transfer agent in its reaction with the palladium complex, which forms a palladium methoxy $\operatorname{species}^{18}$ (eq 1). The higher selectivity

$$
\left[\mathrm{L}_{2} \mathrm{PdX}_{2}\right]+\mathrm{MeOH} \rightarrow\left[\mathrm{L}_{2} \mathrm{Pd}(\mathrm{OMe}) \mathrm{X}\right]+\mathrm{HX}
$$

to the esters is attributed to oxidation by an oxidant (1,4-naphthoquinone) of the proposed palladium species (eq 2).

$$
\begin{aligned}
{\left[\mathrm{L}_{2} \mathrm{Pd}-\mathrm{H}\right] } & +\mathrm{OC}_{10} \mathrm{H}_{8} \mathrm{O}+\mathrm{MeOH} \\
& \rightarrow\left[\mathrm{L}_{2} \mathrm{PdOMe}\right]+\mathrm{HOC}_{10} \mathrm{H}_{8} \mathrm{OH}
\end{aligned}
$$

Reactions in aprotonic solvents in which the copolymerizations are initiated by dihydrogen, presumably involving formation of a palladium hydride species $\left[\mathrm{L}_{2} \mathrm{Pd}-\mathrm{H}\right]$, give decreased yield. ${ }^{18}$ The IR spectra show only one carbonyl group.

Effects of Proportion of Methanol on Copolymerization

Table IV shows the effects of the proportion of methanol on copolymerization. The yield increased but molar mass decreased as methanol was added to the

\begin{tabular}{|c|c|c|c|c|}
\hline $\mathrm{mol} \mathrm{CH}_{3} \mathrm{OH}$ & Yield & Productivity & $v_{\mathrm{C}}=\mathrm{O}$ & $\bar{M}^{\mathrm{b}}$ \\
\hline mol Pd & $\mathrm{g}$ & g copolymer $\mathrm{g}^{-1} \mathrm{Pd} \mathrm{h}^{-1}$ & $\mathrm{~cm}^{-1}$ & $M_{n}$ \\
\hline 0 & 3.02 & 142 & 1690 & 6100 \\
\hline 246 & 7.01 & 329 & 1727,1689 & 5500 \\
\hline 491 & 7.22 & 339 & 1728,1690 & 5300 \\
\hline 737 & 9.12 & 429 & 1728,1691 & 5000 \\
\hline 983 & 9.41 & 442 & 1727,1689 & 4800 \\
\hline 1228 & 10.05 & 472 & 1727,1689 & 4300 \\
\hline
\end{tabular}

Table IV. Effect of proportion of methanol on copolymerization ${ }^{a}$

a Experimental conditions: norbornene $(0.1 \mathrm{~mol})$; THF $(10 \mathrm{ml})$; partial pressure of $\mathrm{CO}, \mathrm{P}(\mathrm{CO})=2.3 \mathrm{MPa} ; \mathrm{Pd}\left(\mathrm{CH}_{3} \mathrm{COO}\right)_{2}(0.1 \mathrm{mmol})$; 2,2'-bipyridine ( $3 \mathrm{mmol})$; $p$-toluenesulfonic acid $(2 \mathrm{mmol})$; nitrobenzene $(20 \mathrm{mmol})$; temperature, $90^{\circ} \mathrm{C}$; reaction period, $2 \mathrm{~h} .{ }^{\mathrm{b}} \bar{M}_{n}$ was measured by osmometry for the copolymer in THF.

reaction solution over the range of $\mathrm{CH}_{3} \mathrm{OH} / \mathrm{Pd}$ mol ratio 246-1228. Drent et al. ${ }^{18}$ reported that a palladium complex reacts with methanol to give a palladium methoxy species (eq 1), followed by nucleophilic attack by $\mathrm{CO}$ (eq 3 ) and subsequent displacement of the anionic ligand. Activation of $\left[\mathrm{L}_{2} \mathrm{PdX}_{2}\right]$ by methanol to form $\left[\mathrm{Pd}-\mathrm{O}-\mathrm{CH}_{3}\right]$ that can initiate polymerization was also proposed by Chien et al. ${ }^{19)}$ When the proportion of $\mathrm{MeOH}$ was increased in the copolymerization system,

$$
\left[\mathrm{L}_{2} \mathrm{Pd}(\mathrm{OMe}) \mathrm{X}\right]+\mathrm{CO} \rightarrow\left[\mathrm{L}_{2} \mathrm{Pd}(\mathrm{CO}) \mathrm{OMe}\right] \mathrm{X}
$$

the concentration of $\left[\mathrm{L}_{2} \mathrm{Pd}(\mathrm{OMe}) \mathrm{X}\right]$ increased. Subsequently, the yield increased but the molar mass decreased.

Effects of Pressure of CO on Copolymerization with NBE

The effects of pressure of $\mathrm{CO}$ on copolymerization with norbornene at $90^{\circ} \mathrm{C}$ was investigated. The greater the pressure of $\mathrm{CO}$, the greater were the yield and molar mass of the NBE/CO copolymer. The copolymerization of $\mathrm{CO}$ and norbornene was considerable $(6.11 \mathrm{~g})$ at pressures as small as $0.67 \mathrm{MPa}$ with $\mathrm{CH}_{3} \mathrm{OH}$ as solvent and with 1,4-naphthoquinone as oxidant. Two absorptions in the IR spectra in $\mathrm{CH}_{3} \mathrm{OH}$ are attributed to the ketone and ester carbonyl groups. The procedure described above for the effects of pressure of $\mathrm{CO}$ on copolymerization was repeated using 1,4-benzoquinone instead of 1,4-naphthoquinone. The final NBE/CO copolymer had almost the same molar mass at the corresponding pressure of $\mathrm{CO}$ but the yield was smaller.

\section{Effects of Duration of Polymerization on Yield and Molar Mass}

The effects of duration of polymerization on yield and molar mass were investigated. The yield increased remarkably during the early stages of copolymerization and remained constant after $5 \mathrm{~h}$. The latter might be explained by diminishing catalytic activity and concentration of $\mathrm{CO}$, but the molar mass slightly increased with duration of polymerization.

\section{Effects of Concentration of Acid on Copolymerization}

The effects of concentration of acid such as p-toluenesulfonic acid on copolymer molar mass are shown in Figure 2. The molar mass decreased with increasing concentration of $p$-toluenesulfonic acid but yield in- 


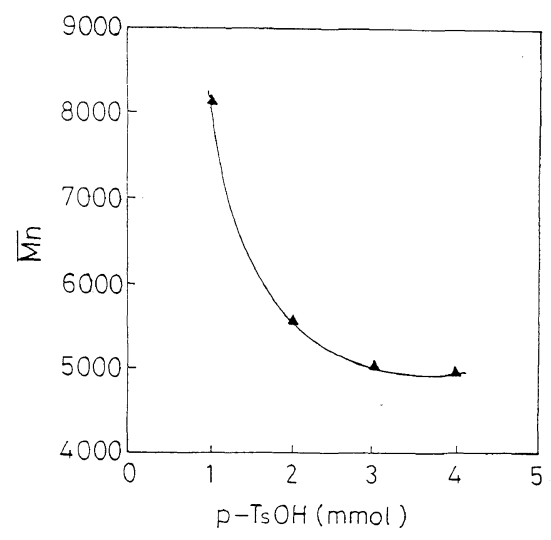

Figure 2. Effects of concentration of $p$-toluenesulfonic acid copolymer molar mass. Experimental conditions: norbornene ( $0.1 \mathrm{~mol})$; THF $(10 \mathrm{ml}) ; \mathrm{Pd}\left(\mathrm{CH}_{3} \mathrm{COO}\right)_{2}(0.1 \mathrm{mmol}) ; 2,2^{\prime}$-bipyridine $(3 \mathrm{mmol}) ;$ nitrobenzene $(20 \mathrm{mmol})$; temperature, $90^{\circ} \mathrm{C}$; partial pressure of $\mathrm{CO}$, $\mathrm{P}(\mathrm{CO})=2.7 \mathrm{MPa}$; reaction duration, $2 \mathrm{~h} . \bar{M}_{n}$ was measured by osmometry for the copolymer in THF.

creased. Drent et al. ${ }^{18}$ reported that a more electrophilic palladium center in acetone solution on addition of $p$-toluenesulfonic acid formed weakly coordinating anions. The replacement of acetate anions by $p$-toluenesulfonate anions is as follows (eq 4):

$$
\begin{aligned}
\mathrm{L}_{2} \mathrm{Pd} & \left(\mathrm{CH}_{3} \mathrm{COO}\right)_{2}+2 \mathrm{HO}_{3} \mathrm{STol} \\
& \rightarrow\left[\mathrm{L}_{2} \mathrm{Pd}\left(\mathrm{O}_{3} \mathrm{STol}\right)_{2}\right]+2 \mathrm{CH}_{3} \mathrm{COOH}
\end{aligned}
$$

Such vacant coordination sites at which catalytic transformations occur are considered to be formed by nucleophilic substitution of the anions for monomer such as $\mathrm{CO}$, or norbornene, or solvent molecules, i.e., for complete nucleophilic substitution (eq 5):

$$
\begin{aligned}
& {\left[\mathrm{L}_{2} \mathrm{Pd}\left(\mathrm{O}_{3} \mathrm{STol}\right)_{2}\right]+2(\mathrm{Nuc})} \\
& \quad \rightarrow\left[\mathrm{L}_{2} \mathrm{Pd}(\mathrm{Nuc})_{2}\right]^{+2}+2\left(\mathrm{O}_{3} \mathrm{STol}\right)^{-} .
\end{aligned}
$$

The increased reactivity of catalytic systems formed from such anions partly stems from easier access of substrate molecules, solvent, norbornene and $\mathrm{CO}$, to coordination sites on the metal center. ${ }^{18}$

Drent et al. ${ }^{18)}$ reported that $p$-toluenesulfonic acid is an essential co-catalyst in the catalytic system $\mathrm{Ph}_{2} \mathrm{P}\left(\mathrm{CH}_{2}\right) \mathrm{PPh}_{2} \cdot \mathrm{Pd}\left(\mathrm{CH}_{3} \mathrm{COO}\right)_{2} / p$ - TsOH. The yield increased but the molar mass decreased when the active species of $\mathrm{L}_{2} \mathrm{Pd}\left(\mathrm{O}_{3} \mathrm{STol}\right)_{2}$ was increased. This was also observed by Chien et al. in the copolymerization of ethylene and carbon monoxide. ${ }^{19}$

Effects of Concentration of Oxidant on Copolymerization

The effects of the concentration of an oxidant such as 1,4-benzoquinone on copolymerization yield are shown in Table V. 1,4-Benzoquinone was added to promote the reaction. ${ }^{18,22,36}$ The yield increased with concentration of 1,4-benzoquinone, whereas the glass transition temperature decreased. This may be due to the increased palladium methoxy species obtained from reaction of oxidant (1,4-benzoquinone) and palladium hydride species $\left[\mathrm{L}_{2} \mathrm{Pd}-\mathrm{H}\right]$ in a protonic solvent (eq 6),

$$
\begin{aligned}
& {\left[\mathrm{L}_{2} \mathrm{Pd}-\mathrm{H}\right]+\mathrm{OC}_{6} \mathrm{H}_{4} \mathrm{O}+\mathrm{MeOH}} \\
& \quad \rightarrow\left[\mathrm{L}_{2} \mathrm{Pd}-\mathrm{OMe}\right]+\mathrm{HOC}_{6} \mathrm{H}_{4} \mathrm{OH}
\end{aligned}
$$

\begin{tabular}{|c|c|c|c|c|}
\hline 1,4-Benzoquinone & Yield & Productivity & $v_{\mathrm{C}=\mathrm{O}}$ & $T_{\mathrm{g}}^{\mathrm{b}}$ \\
\hline $\mathrm{mmol}$ & $\mathrm{g}$ & $\mathrm{g}$ copolymer $\mathrm{g}^{-1} \mathrm{Pd} \mathrm{h}^{-1}$ & $\mathrm{~cm}^{-1}$ & ${ }^{\circ} \mathrm{C}$ \\
\hline 2.5 & 5.21 & 245 & 1723,1694 & 141 \\
\hline 5 & 5.41 & 254 & 1725,1692 & 137 \\
\hline 20 & 8.95 & 421 & 1728,1692 & 103 \\
\hline
\end{tabular}

and may result in decreased molar mass. As mentioned
Table V. Effect of concentration of oxidant on copolymerization ${ }^{\mathrm{a}}$

${ }^{\text {a }}$ Experimental conditions: norbornene $(0.1 \mathrm{~mol})$; $\mathrm{CH}_{3} \mathrm{OH}(10 \mathrm{ml})$; $\mathrm{Pd}\left(\mathrm{CH}_{3} \mathrm{COO}\right)_{2} \quad(0.1 \mathrm{mmol}) ; 2,2^{\prime}$-bipyridine $(3 \mathrm{mmol})$; temperature: $90^{\circ} \mathrm{C}$; partial pressure of $\mathrm{CO}, \mathrm{P}(\mathrm{CO})=3.3 \mathrm{MPa}$; reaction period, $2 \mathrm{~h}$. ${ }^{\mathrm{b}}$ Measured by DSC; heating rate, $20^{\circ} \mathrm{C} \mathrm{min}^{-1}$.

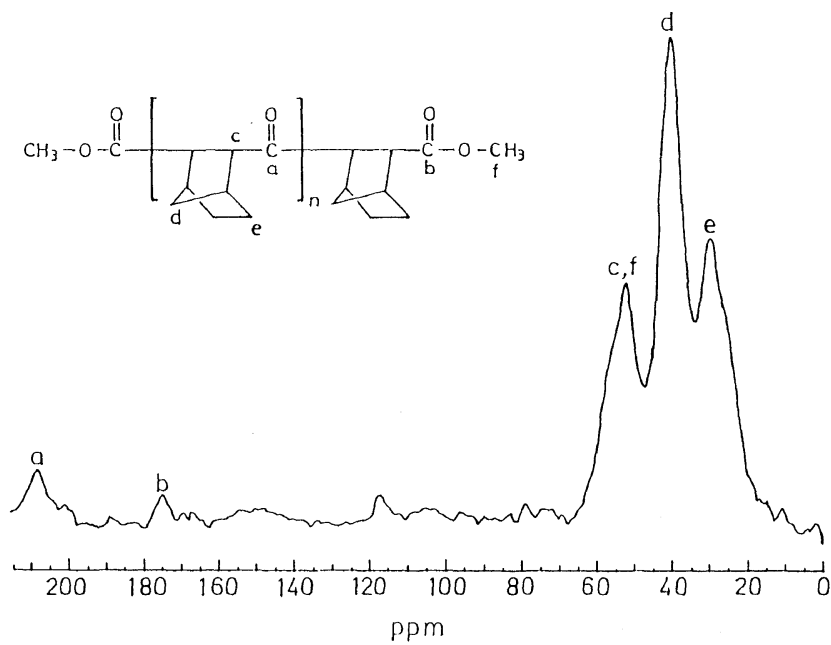

Figure 3. Solid-state ${ }^{13} \mathrm{C}$ NMR spectrum of $\mathrm{NBE} / \mathrm{CO}$ copolymer. Copolymerization conditions: norbornene $(0.1 \mathrm{~mol})$; methanol $(10 \mathrm{ml})$; partial pressure of $\mathrm{CO}, \mathrm{P}(\mathrm{CO})=2.7 \mathrm{MPa} ; \mathrm{Pd}\left(\mathrm{CH}_{3} \mathrm{COO}\right)_{2}(0.1 \mathrm{mmol})$; $2,2^{\prime}$-bipyridine ( $\left.3 \mathrm{mmol}\right) ; p$-toluenesulfonic acid $(2 \mathrm{mmol})$; nitrobenzene $(40 \mathrm{mmol})$; reaction duration, $2 \mathrm{~h}$.

above, the NBE/CO copolymers obtained from 1,4benzoquinone were insoluble in common organic solvents, and thus the molar mass could not be measured.

\section{Characterization of NBE/CO Copolymer by IR, ${ }^{1} \mathrm{H} N M R$ and Solid-State ${ }^{13} C N M R$}

The copolymer of norbornene and $\mathrm{CO}$ was almost insoluble in common organic solvents, and thus was characterized by IR, ${ }^{1} \mathrm{H}$, and solid-state ${ }^{13} \mathrm{C}$ NMR spectroscopy and supported by elemental analysis. A strong IR absorption about $1690 \mathrm{~cm}^{-1}$ is ascribed to the carbonyl group. The ${ }^{1} \mathrm{H}$ NMR $\left(\mathrm{CDCl}_{3}\right)$ spectrum of the copolymer for soluble parts exhibited broad signals at $0.60-3.75 \mathrm{ppm}$ indicating that the copolymer contained ring structures. ${ }^{20}$ ) According to Figure 3 (solid-state ${ }^{13} \mathrm{C}$ NMR spectrum), the signal at $208.0 \mathrm{ppm}$ is ascribed to the carbonyl carbon. The line at $174.8 \mathrm{ppm}$ is due to the carbonyl group $\left(\mathrm{CH}_{3}-\mathrm{O}-(\mathrm{C}=\mathrm{O})-\right)$ at the end of the copolymer chain. The signals at $52.2,40.7$, and $29.7 \mathrm{ppm}$ also support that $\mathrm{NBE} / \mathrm{CO}$ copolymer contain ring structures. The signal of methyl group at the end of the copolymer chain overlaps with the ring structure of $\mathrm{NBE} / \mathrm{CO}$ copolymer at $52.2 \mathrm{ppm}$. This further proves that $\mathrm{CO}$ is indeed copolymerized with norbornene.

\section{$X$-Ray Diffractogram of Copolymer}

Figure 4 shows the X-Ray diffractogram of the co- 


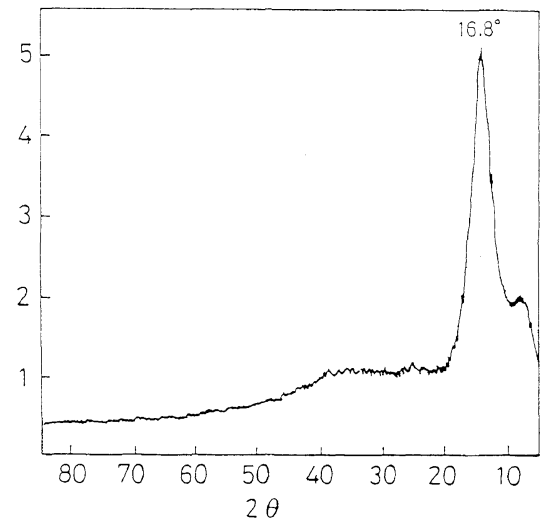

Figure 4. X-Ray diffractogram of NBE/CO copolymer. Copolymerization conditions: norbornene $(0.1 \mathrm{~mol})$; methanol $(10 \mathrm{ml})$; partial pressure of $\mathrm{CO}, \mathrm{P}(\mathrm{CO})=2.7 \mathrm{MPa} ; \mathrm{Pd}\left(\mathrm{CH}_{3} \mathrm{COO}\right)_{2}(0.1 \mathrm{mmol}) ; 2,2^{\prime}$ bipyridine $(3 \mathrm{mmol})$; $p$-toluenesulfonic acid $(2 \mathrm{mmol})$; nitrobenzene $(40 \mathrm{mmol})$; reaction duration, $2 \mathrm{~h}$.

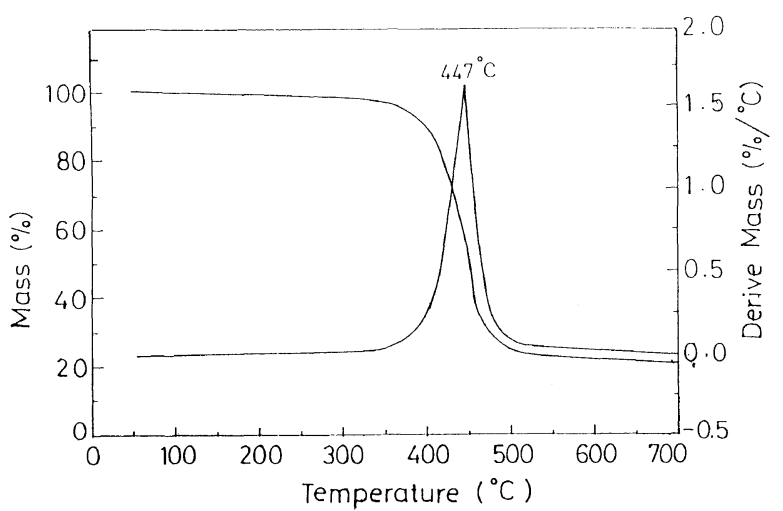

Figure 5. TGA curve of $\mathrm{NBE} / \mathrm{CO}$ copolymer in nitrogen (heating rate $\left.20 \mathrm{C} \mathrm{min}^{-1}\right)$. Copolymerization conditions: norbornene $(0.1$ $\mathrm{mol})$; methanol $(10 \mathrm{ml})$; partial pressure of $\mathrm{CO}, \mathrm{P}(\mathrm{CO})=2.7 \mathrm{MPa}$; $\mathrm{Pd}\left(\mathrm{CH}_{3} \mathrm{COO}\right)_{2}(0.1 \mathrm{mmol}) ; 2,2^{\prime}$-bipyridine $(3 \mathrm{mmol}) ;$-toluenesulfonic acid $(2 \mathrm{mmol})$; nitrobenzene $(40 \mathrm{mmol})$; reaction duration, $2 \mathrm{~h}$.

polymer. The copolymer was confirmed to be partially crystalline. The shape of the X-Ray diffractogram diagram of this copolymer from a Pd catalyst was similar to that of a copolymer formed on $\gamma$ irradiation. ${ }^{21}$

\section{Thermogravimetric Analysis of $\mathrm{NBE} / \mathrm{CO}$ Copolymer}

A TGA curve of the copolymer of norbornene and $\mathrm{CO}$ appears in Figure 5 with a heating rate, $20^{\circ} \mathrm{C} \mathrm{min}^{-1}$ in nitrogen. Figure 5 shows that loss of mass starts at $350^{\circ} \mathrm{C}$. The maximum decomposition occurs at $447^{\circ} \mathrm{C}$ according to the differential thermogravimetric analysis curve.

\section{Hydrogenation}

Hydrogenation of the polyketone with the reduction agent (lithium aluminum hydride, $\mathrm{LiAlH}_{4}$ ) in THF yielded hydroxyl-containing polymer having units represented as in (eq 7) and Figure 6. The hydrogenated polymer was completely soluble in

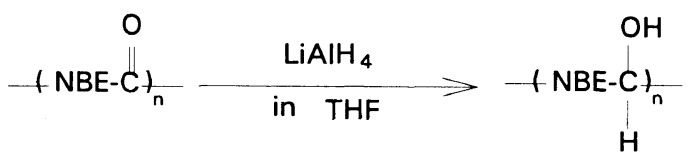

chloroform, conc. $\mathrm{H}_{2} \mathrm{SO}_{4}$, THF, dimethylforamide, pyridine, and chlorobenzene, partially soluble in di-

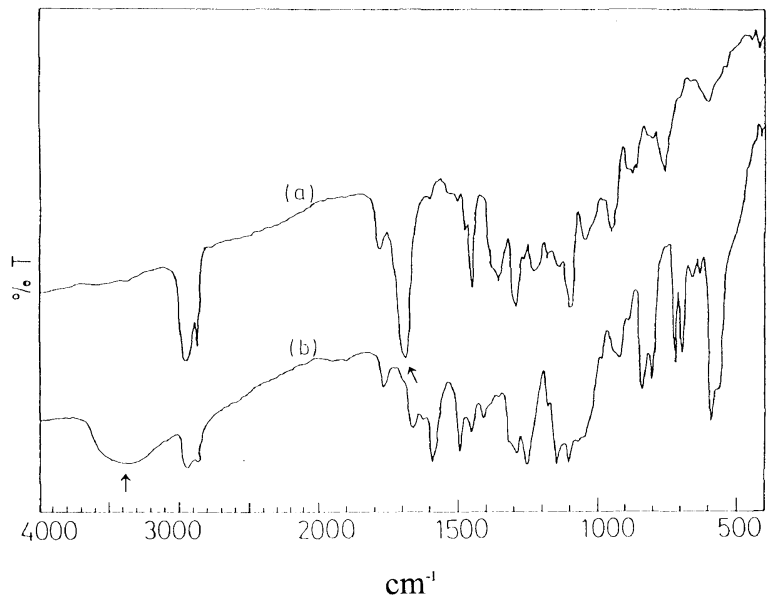

Figure 6. IR spectra of the hydrogenation of polyketone with a reducting agent (lithium aluminum hydride, $\mathrm{LiAlH}_{4}$ ) in THF: (a) before; (b) after hydrogenation.

methylacetamide, dimethylsulfoxide, acetone, and insoluble in benzene, xylene, toluene, acetonitrile, 1,2dichloroethane, and $m$-cresol. The absence of infrared absorption corresponding to the carbonyl group [1690 $\mathrm{cm}^{-1}$, Figure 6(a)] and a specific absorption of $v_{\mathrm{OH}}$ at $3396 \mathrm{~cm}^{-1}$ [Figure 6(b)] indicated the essentially complete conversion of ketone functional groups to alcohol groups without cleavage of the polyketone chain. According to the ${ }^{13} \mathrm{C}$ NMR spectrum, the appearance of the signal due to the methine group at $68 \mathrm{ppm}$ and the disappearance of the signal due to the carbonyl group at $208 \mathrm{ppm}$ after hydrogenation support the complete hydrogenation of the polyketone.

Acknowledgement. We thank the National Science Council of the Republic of China for financial support (grant NSC 83-0405-E011-003 and grant NSC 83-0405E011-017)

\section{REFERENCES AND NOTES}

1. M. M. Brubaker, D. D. Coffman, and H. H. Hoehn, J. Am Chem. Soc., 74, 1509 (1952).

2. M. M. Brubaker, U. S. Patent 2495286 (1950).

3. A. Sen, Adv. Polym. Sci., 73/74, 125 (1986).

4. M. Heskin and J. E. Guillet, Macromolecules, 3, 224 (1970).

5. G. H. Hartley and J. E. Guillet, Macromolecules, 1, 413 (1968)

6. G. H. Hartley and J. E. Guillet, Macromolecules, 1, 165 (1968).

7. M. M. Brubaker, D. D. Coffman, and H. H. Hoehn, J. Am Chem. Soc., 74, 1509 (1952).

8. Y. Morishima, T. Tadizawa, and S. Murahashi, Eur. Polym. J., 9, 669 (1973).

9. K. Nozaki, U. S. Patent 3835123 (1974)

10. K. Nozaki, U. S. Patent 3694412 (1972).

11. K. Nozaki, U. S. Patent 3689460 (1972).

12. D. M. Fenton, U. S. Patent 3530109 (1970).

13. A. Sen and T. W. Lai, J. Am. Chem. Soc., 104, 3520 (1982).

14. T. W. Lai and A. Sen, Organometallics, 3, 866 (1984).

15. E. Drent, U. S. Patent 4788279 (1988)

16. E. Drent, Eur. Pat. Appl., 351023 (1990).

17. D. J. Liaw, J. Polym. Sci., Polym. Chem. Ed., 31, 309 (1993).

18. E. Drent, J. A. M. Van Broekhoven and M. J. Doyle, J. Organomet. Chem., 417, 235 (1991).

19. A. X. Zhao and J. C. W. Chien, J. Polym. Sci., Polym. Chem. Ed., 30, 2735 (1992).

20. F. Hojabri, M. M. Mohaddes, and A. Talab, Polymer, 17, 710 (1976). 
21. T. Kagiya, M. Kondo, K. Fukui, and H. Yokoya, J. Polym. Sci., $A-1,7,2739$ (1969).

22. A. Sen and Z. Jiang, Macromolecules, 26, 911 (1993).

23. M. Brookhart, F. C. Rix, and J. M. DeSimone, J. Am. Chem. Soc., 114, 5894 (1992).

24. A. Batistini, G. Consiglio, and U. W. Suter, Angew: Chem. Int Ed. Engl., 31, 303 (1992).

25. M. Barsacchi, A. Batistini, G. Consiglio, and U. W. Suter, Macromolecules, 25, 3604 (1992).

26. Z. Jiang, G. M. Dahlen, K. Houseknecht, and A. Sen, Macromolecules, 25, 2999 (1992).

27. J. C. W. Chien, A. X. Zhao, and F. Xu, Polym. Bull, 28, 315 (1992).

28. M. Barsacchi, G. Consiglio, L. Medici, G. Petrucci, and U. W.
Suter, Angew. Chem., Int. Ed. Engl., 30, 989 (1991).

29. E. Drent. Eur. Patent Appl., 390292 (1990).

30. P. W. Van Leeuwen, C. F. Roobeek, and P. K. Wong, Eur. Patent Appl., 393790 (1990).

31. J. Van Broekhoven, Eur. Patent Appl., 361584 (1989).

32. E. Drent and R. L. Wife, Eur. Patent Appl., 322018 (1988).

33. E. Drent, Eur. Patent Appl., 181014 (1985).

34. J. Tsuji and S. Hosaka, J. Polym. Sci., Part B, 3, 723 (1965).

35. C. Pisano, A. Messetti, and G. Consiglio, Organometallics, 11 20 (1992).

36. V. Busico, P. Dorradini, L. Landriani, and M. Trifuoggi, Makromol. Chem., Rapid Commun., 14, 261 (1993).

37. F. Y. Xu, A. X. Zhao, and J. C. W. Chien, Makromol. Chem., 194, 2579 (1993). 